\title{
Model Creative Art Dalam Konseling Untuk Meningkatkan Empati dan Hubungan Interpersonal Pada Mahasiswa Politeknik Lp3i Medan Kampus Medan Baru
}

\section{Creative Arts Models in Counseling to Increase Empathy and Interpersonal Relationships in Students}

\author{
Ira Kesuma Dewi \\ Fakultas Psikologi Universitas Medan Area, Indonesia \\ Diterima : 13 April 2020; Disetujui : 17 April 2020; Dipublish : 30 April 2020 \\ *Corresponding author: E-mail: irakesumadewi@gmail.com
}

\begin{abstract}
Abstrak
Penelitian ini bertujuan mengembangkan model creative art dalam konseling untuk meningkatkan empati dan hubungan interpersonal pada mahasiswa di Politeknik LP3I Medan Kampus Medan Baru. Metode yang digunakan adalah penelitian pengembangan (research and development) Borg and Gall. Pengembangan model creative art dalam konseling ini divalidasi oleh ahli konseling, ahli bahasa, dan di uji kepraktisannya oleh SCC sebagai pengguna model. Untuk mengetahui keberhasilan model creative art dalam konseling digunakan skala empati dan hubungan interpersonal. Data dianalisis dengan menggunakan t-test pada program SPSS Versi 16.0 for windows. Objek dalam penelitian ini adalah mahasiswa Politeknik LP3i Medan terdiri dari 43 Orang. Selanjutnya, mahasiswa yang dijadikan subjek penelitian dipilih secara purposive dengan karakter memiliki skor rendah yang dibagi dalam dua kelompok, yaitu kelompok eksperimen dan kelompok kontrol. Hasil penelitian menunjukkan model creative art dalam konseling efektif digunakan untuk meningkatkan empati dan hubungan interpersonal pada mahasiswa. Nilai $t$ $=0.043$ dengan $\mathrm{p}<0.05$, artinya terjadi peningkatan empati pada mahasiswa setelah diterapkan model creative art dalam konseling. Nilai $\mathrm{t}=0,046$ dengan $\mathrm{p}<0.05$, artinya terjadi peningkatan hubungan interpersonal pada mahasiswa setelah diterapkan model creative art dalam konseling. Penelitian ini menyimpulkan bahwa penggunaan model creative art dalam konseling dapat meningkatkan empati dan hubungan interpersonal pada mahasiswa.

Kata Kunci : Empati; Hubungan Interpersonal; Model Creative Art.
\end{abstract}

\begin{abstract}
This study aims to develop a creative art model in counseling to improve empathy and interpersonal relationships in students at the Polytechnic LP3i Medan, Medan Baru Campus. The method is research and development by Borg and Gall. This models was validated by counseling experts, linguists, and by the SCC as a model user. To find out the success of the model, used empathy and interpersonal relationships scale. Data were analyzed using t-test in SPSS Version 16.0 for Windows. The object of this research is the students at the Polytechnic LP3i Medan consisting of 43 people. Furthermore, students are selected purposively with characters having a low score divided into two groups, namely the experim ental group and the control group. The results showed that the creative art model in counseling was effective to used to improve empathy and interpersonal relationships in students. $T$ value $=0.043$ with $p<0.05$ for empathy and $T$ value $=0.046$ with $p<0.05$ for interpersonal relationships, meaning that an increase in empathy and interpersonal relationships in students after applying the creative art model in counseling. This study concludes that the use of creative art models in counseling can improve empathy and interpersonal relationships in students.
\end{abstract}

Keywords: Empathy; Interpersonal Relations; Creative Art Models.

\section{Rekomendasi mensitasi :}

Dewi, I.K. (2020). Model Creative Art Dalam Konseling Untuk Meningkatkan Empati dan Hubungan Interpersona Pada Mahasiswa Politeknik Lp3i Medan Kampus Medan Baru. Jurnal Penelitian Pendidikan, Psikologi dan Kesehatan (J-P3K), 1(1): 34-43. 


\section{PENDAHULUAN}

Pendidikan di perguruan tinggi diharapkan mampu menciptakan mahasiswa selaku pemuda yang memiliki karakteristik dengan identitas ego yang mencapai kematangan, memiliki hubungan interpersonal yang semakin baik, memiliki pendalaman setiap minat, memahami nilainilai, dan memiliki rasa empati. Untuk mencapai karakteristik tersebut seharusnya dalam diri mahasiswa juga dibentuk sebuah karakter yang akan mempengaruhi dan berperan dalam pencapaian fungsi mahasiswa sebagai control social dan agent of change.

Empati adalah kemampuan seseorang untuk memahami, merasakan dan merespons orang lain yang tengah tertimpa kesusahan dengan melibatkan emosinya secara tulus. Seorang yang empatik bisa menerima resonansi emosi penderitaan orang lain. Ada keterlibatan emosi sehingga lawan bicara akan amat termotivasi tatkala seseorang mampu menunjukkan empatinya (Mahyudin, 2009:163).

Ketika melakukan komunikasi dan interaksi dengan orang lain atau yang biasa disebut hubungan interpersonal tidak hanya proses komunikasi yang berlangsung, tetapi terjadi proses penilaian dan empati dengan lawan bicara agar tujuan dari hubungan tersebut dapat dicapai. Hubungan interpersonal bukan hanya sekedar menyampaikan isi pesan yang dimaksud tetapi juga kadar hubungan yang diinginkan. Jadi, ketika mahasiswa berkenalan dengan orang lain atau dengan teman sebaya di lingkungan kampus, dia akan menilai apakah orang tersebut layak untuk dijadikan teman dekat atau tidak. Jika memilih untuk menjadikannya sebagai teman dekat maka kegaiatan saling berinteraksi akan dilakukan, jika tidak maka akan menghindari untuk melakukan interaksi dengan orang tersebut. Hubungan interpersonal adalah hubungan yang terdiri dari dua orang atau lebih yang saling tergantung satu sama lain dan menggunakan pola interaksi yang konsisten (Dian dan Srifatmawati, 2012:2).

Pada kenyataanya tidak semua mahasiswa mampu untuk berempati sehingga hubungan interpersonal dan sosialisasinya tidak berjalan dengan baik. Berdasarkan observasi dan wawancara yang dilakukan oleh Sutanti (2015) pada saat proses perkuliahan pada mata kuliah teori dan teknik konseling dan pemahaman tingkah laku, menunjukkan bahwa rasa kepedulian yang dimiliki mahasiswa BK UAD angkatan 2011 masih rendah.

Hasil observasi yang dilakukan oleh peneliti di Politeknik LP3i Medan Kampus Medan Baru pada bulan Januari 2018 ditemukan bahwa dari 30 orang mahasiswa dua diantaranya tidak peduli terhadap lingkungan dan teman-teman sesama mahasiswa, sulit memaafkan, pemarah dan pendendam serta kurang empati terhadap sesamanya dan dua puluh delapan lainnya masih kurang kepedulian dan empatinya terhadap sesama.

Untuk mengatasi permasalahan kurangnya empati sehingga berdampak pada sulitnya menjalin hubungan interpersonal dengan orang lain ada banyak cara yang dilakukan salah satunya adalah konseling dengan model creative art. Konseling dengan creative art dilakukan dengan menggunakan berbagai media seni dan kreativitas di dalam prosesnya (Milfa, 2017). 
Creative art dalam konseling adalah suatu bentuk seni, baik verbal maupun nonverbal, memiliki rasa peka atau memfasilitasi keterlibatan klien ke dalam konseling dan memungkinkan individu untuk tumbuh dan berkembang dengan cara yang fungsional dan sehat. Efek jangka panjang yang ditimbulkan creative art pada proses konseling akan memperkaya para konselor untuk lebih peka terhadap kreatifitas yang dilakukan oleh klien sehingga menciptakan kesadaran terhadap apa yang dirasakan oleh klien kemungkinan akan lebih besar (Jourard St Landsman dalam Gladding, 1992:2).

Pengembangan model creative art dilakukan melalui penelitian dan pengembangan. Dengan cara ini diharapkan diperoleh suatu produk model konseling yang dilengkapi dengan buku pedoman pelaksanaan konseling terhadap mahasiswa di Politeknik LP3i Medan Kampus Medan Baru. Dengan produk ini SCC (Student Care Center) dapat mengidentifikasi permasalahan pada mahasiswa. Kedua menetapkan tujuan dan prosedur dalam melaksanakan konseling pada mahasiswa, kemudian mengembangkan prosedur tersebut dalam setiap kegiatan konseling yang akan dilaksanakan secara rutin sekali dalam satu minggu dan sekaligus sebagai media yang relevan untuk mengatasi masalah dengan karakteristik yang sama dikalangan mahasiswa tingkat I, II maupun mahasiswa ditingkat akhir. Beranjak dari pemikiran ini maka dilakukan sebuah penelitian yang berjudul "Model Creative Art dalam konseling Untuk Meningkatkan Empati Dan Hubungan Interpersonal Teman Sebaya Pada Mahasiswa Politeknik Lp3i Medan Kampus Medan Baru."
Penelitian ini bertujuan menyusun model creative art dalam konseling untuk meningkatkan empati dan hubungan interpersonal mahasiswa Politeknik LP3I Medan Kampus Medan Baru dapat tersusun dengan spesifikasi sintaks, sistem sosial, prinsip-prinsip reaksi yang dituangkan dalam buku panduan pelaksanaan berikut lembar evaluasi perkembangan. Selanjutnya penelitian ini akan menguji kepraktisan model creative art dalam konseling untuk meningkatkan empati dan hubungan interpersonal mahasiswa Politeknik LP3I Medan Kampus Medan Baru sehingga dapat diterapkan oleh pihak kemahasiswaan dan SCC (Student Care Center) di kampus.

Agar jenis-jenis layanan konseling dan kegiatan pendukung berjalan dengan sebaik-baiknya, maka setiap jenis layanan dan kegiatan pendukung itu perlu diselenggarakan dengan memenuhi standar prosedur operasional (SPO) yang ditentukan. SPO yang dimaksud meliputi langkah-langkah "Lima-an" sebagai berikut (Prayitno dalam Prayitno, 2015: 102-104) : Pengantaran, penjajagan, penafsiran, pembinaan, penilaian.

Hipotesis yang dikemukakan dalam penelitian sebagai berirkut : Buku panduan model creative art dalam konseling untuk meningkatkan empati dan hubungan interpersonal dapat dikembangkan melalui penelitian pengembangan. Modul/buku panduan model creative art dalam konseling untuk meningkatkan empati dan hubungan interpersonal mahasiswa Politeknik Lp3i Medan Kampus Medan Baru praktis digunakan. Modul/buku panduan model creative art dalam konseling dapat meningkatkan empati mahasiswa Politeknik Lp3i Medan Kampus 
Medan Baru. Modul/buku panduan model creative art dalam konseling dapat meningkatkan hubungan interpersonal mahasiswa Politeknik Lp3i Medan Kampus Medan Baru.

\section{METODE PENELITIAN}

Jenis penelitian ini adalah penelitian pengembangan (Research and Development). Metode penelitian pengembangan merupakan metode yang digunakan untuk menghasilkan suatu produk tertentu dengan menguji keefektifan produk tersebut (Sugiyono, 2011:407). Penelitian ini mengacu pada model pengembangan R\&D yang dikemukakan oleh Borg dan Gall (dalam Sugiyono, 2015:35-36). Dalam penelitian ini, penerapan langkah-langkah penelitian dan pegembangan tersebut disesuaikan dengan kebutuhan peneliti, mengingat keterbatasan waktu dan dana yang dimiliki oleh peneliti. Maka langkah-langkah tersebut disederhanakan menjadi lima langkah pengembangan, yaitu pengumpulan data, perencanaan, pengembangan produk, penyempurnaan produk, dan Penyebaran/diseminasi dan implementasi.

Penelitian ini dilakukan di Politeknik Lp3i Medan Kampus Medan Baru, beralamat di jalan Sei Serayu No. 48D Medan. Berdasarkan hasil wawancara dan observasi pendahuluan maka mahasiswa program studi akuntansi dan program studi teknologi komputer angkatan 2016 yang memenuhi kreteria untuk menjadi subjek penelitian. 6 anak yang terdiri dari 3 kelompok eksperimen dari program studi akuntnasi angkatan 2016, dan 3 kelompok kontrol dari program studi teknologi komputer angkatan 2016. Sedangkan objek dalam penelitian ini adalah pengembangan buku panduan SCC konseling dalam model creative art untuk membantu meningkatkan empati dan hubungan interpersonal mahasiswa.

Jenis metode yang digunakan dalam penelitian ini adalah metode observasi. Observasi yang digunakan dalam penelitian ini adalah observasi non partisipan dimana peneliti hanya melakukan pengamatan saja. Dalam penelitian ini, peneliti membuat lembar observasi dalam layanan konseling dan skala untuk mengukur penerapan model creative art dalam konseling untuk meningkatkan empati dan hubungan interpersonal pada mahasiswa yang diberikan sebelum dan sesudah perlakuan. Lembar observasi mencakup penghantaran, penjajakan, penafsiran, pembinaan, dan penilaian/evaluasi dalam layanan konseling selama penelitian.

Alat bantu yang digunakan berupa daftar cheklist layanan konseling yang menilai penghantaran, penjajakan, penafsiran, pembinaan, dan penilaian/evaluasi. Sedangkan skala untuk mengukur keberhasilan penerapan model creative art dalam konseling untuk meningkatkan empati dan hubungan interpersonal pada mahasiswa digunakan skala 4 dengan kategori sangat setuju (4), setuju (3), tidak setuju (2) dan sangat tidak setuju (1).

Teknik analisis data yang digunakan dalam penelitian ini adalah teknik analisis data deskriptif. Tujuan validasi data dalam penelitian ini adalah menjawab kevalidan, kepraktisan dan keefektifan buku panduan "model creative art dalam konseling untuk meningkatkan empati dan hubungan interpersonal pada mahasiswa" yang dikembangkan. Untuk menguji hipotesis 
digunakan uji beda t-tes dalam statistik non parametrik. Uji - $\mathrm{t}$ yang digunakan adalah uji dua beda mean, karena data yang digunakan merupakan data kelompok eksperimen pretest dan posttest. Analisis validitas yang digunakan adalah dengan melihat nilai Corrected Item-Total Correlation atau yang disebut dengan $\mathrm{r}$ hitung. Kemudian nilai r-hitung dibandingkan dengan nilai r-tabel. Sementara itu teknik estimasi reliabilitas yang digunakan adalah teknik koefisien Alpha Cronbach. Pengujian menggunakan bantuan komputer Program statistik SPSS.

\section{HASIL DAN PEMBAHASAN}

Berdasarkan hasil uji coba yang dilakukan pada kelompok eksperimen pada 3 orang mahasiswa untuk menentukan seberapa besar keefektifan buku panduan model creative art dalam konseling untuk meningkatkan empati dan hubungan interpersonal pada mahasiswa berdasarkan pretest dan postest yang dilakukan. Perolehan hasil pretest dan postest pada 3 orang mahasiswa Politeknik LP3I Medan Kampus Medan Baru dapat dilihat pada gambar di bawah ini:

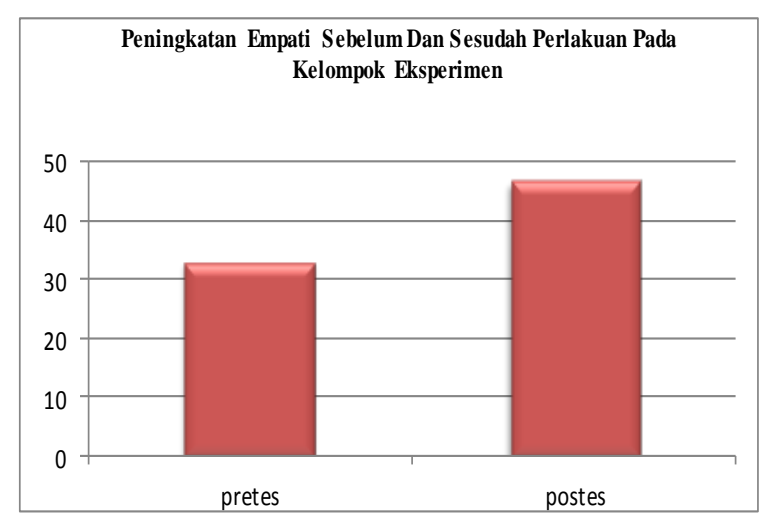

Gambar 1. Peningkatan Empati Sebelum dan Sesudah Perlakuan
Pada gambar di atas menunjukkan perbedaan peningkatan empati secara umum sebelum dan sesudah diberikan perlakuan. Sebelum diberikan perlakuan secara umum peningkatan empati berada pada rata-rata 33. Penilaian tersebut berada pada kategori rendah. Namun setelah diberikan perlakukan dengan menerapkan buku panduan layanan konseling model creative art peningkatan empati secara umum berada pada rata-rata 46,67 . Penilaian ini berada pada kategori tinggi dengan kenaikan sebesar 13,67 atau sebesar $41 \%$.

Sedangkan peningkatan hubungan interpersonal digambarkan pada gambar berikut ini:

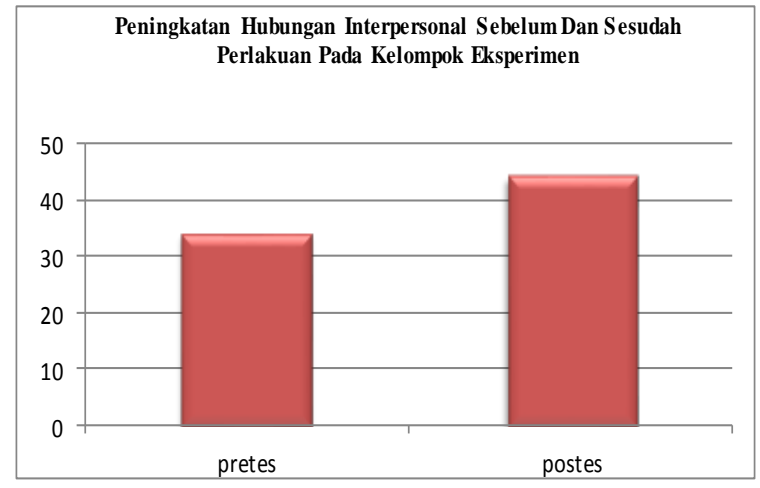

Gambar 2. Peningkatan Hubungan Interpersonal Sebelum dan Sesudah Perlakuan

Secara umum peningkatan hubungan interpersonal sebelum diberikan perlakuan berada pada rata-rata 34. Penilaian tersebut berada pada kategori sedang. Sedangkan setelah diberi perlakuan, hubungan interpersonal menjadi meningkat dengan rata-rata 44 . Penilaian ini berada pada kategori tinggi dengan selisih skor sebesar 10 atau sama dengan $29 \%$ pada nilai persentase.

Berdasarkan hasil uji coba yang dilakukan pada kelas eksperimen pada 3 orang mahasiswa RN, TW dan AD untuk 
menentukan seberapa besar keefektifan buku panduan model creative art dalam konseling untuk meningkatkan empati dan hubungan interpersonal pada mahasiswa berdasarkan pretest dan postest yang dilakukan. Perolehan hasil pre test dan post test empati pada 3 orang mahasiswa program studi akuntansi dapat dilihat pada tabel dibawah ini:

Tabel 1. Hasil pre test dan post test empati pada subjek RN

\begin{tabular}{|c|c|c|c|c|}
\hline \multirow[t]{2}{*}{ Aspek } & \multirow{2}{*}{$\begin{array}{l}\text { Prete } \\
\text { st }\end{array}$} & \multirow{2}{*}{$\begin{array}{l}\text { Postt } \\
\text { est }\end{array}$} & \multicolumn{2}{|c|}{ Selisih } \\
\hline & & & $\begin{array}{l}\text { Sko } \\
\text { r }\end{array}$ & $\begin{array}{l}\text { Persentas } \\
\text { i }\end{array}$ \\
\hline $\begin{array}{l}\text { Ikut } \\
\text { merasakan }\end{array}$ & 6 & 12 & 6 & $100 \%$ \\
\hline Dibangun & & & & \\
\hline diri & 6 & 8 & 2 & $33 \%$ \\
\hline $\begin{array}{l}\text { Peka } \\
\text { terhadap } \\
\text { isvarat }\end{array}$ & 5 & 8 & 3 & $60 \%$ \\
\hline $\begin{array}{l}\text { Mengambil } \\
\text { peran }\end{array}$ & 9 & 12 & 3 & $33 \%$ \\
\hline $\begin{array}{l}\text { Kontrol } \\
\text { emosi }\end{array}$ & 9 & 12 & 3 & $33 \%$ \\
\hline Total & 35 & 52 & 17 & $49 \%$ \\
\hline Rata-rata & 7 & 10,4 & - & - \\
\hline
\end{tabular}

Berdasarkan tabel di atas dapat dilihat bahwa subjek RN pada aspek peka terhadap bahasa isyarat mendapatkan skor terendah yakni 5 dan mengalami peningkatan menjadi 8 setelah diberikan konseling yang berarti mengalami peningkatan sebesar 60\%. Pada aspek ikut merasakan sebelum diberikan konseling skor nya 6 dan meningkat menjadi 12 setelah diberikan konseling, artinya terjadi peningkatan $100 \%$. Pada aspek empati yang dibangun berdasarkan kesadaran diri, mengambil peran, dan kontrol emosi terjadi peningkatan sebesar 33\%. Dengan demikian empati pada RN meningkat dari rendah dengan skor total sebesar 35 menjadi sangat tinggi dengan skor 52 setelah diberikan konseling atau secara keseluruhan terjadi peningkatan sebesar $49 \%$.
Pada subjek TW hasil pre test dan post test empati dapat dilihat pada tabel di bawah ini:

Tabel 2. Hasil pre test dan post test empati pada subjek TW

\begin{tabular}{lcccc}
\hline \multicolumn{1}{c}{ Aspek } & Pretest & Posttest & \multicolumn{2}{c}{ Selisih } \\
& & & Skor & Persentasi \\
\hline $\begin{array}{l}\text { Ikut } \\
\text { merasakan }\end{array}$ & 6 & 9 & 3 & $50 \%$ \\
$\begin{array}{l}\text { Dibangun } \\
\text { berdasarkan }\end{array}$ & 7 & 7 & 0 & $0 \%$ \\
$\begin{array}{l}\text { kesadaran } \\
\text { diri }\end{array}$ & & & & \\
$\begin{array}{l}\text { Peka } \\
\text { terhadap }\end{array}$ & 4 & 6 & 2 & $50 \%$ \\
isyarat & & & & \\
$\begin{array}{l}\text { Mengambil } \\
\text { peran }\end{array}$ & 10 & 12 & 2 & $20 \%$ \\
$\begin{array}{l}\text { Kontrol } \\
\text { emosi }\end{array}$ & 8 & 10 & 2 & $25 \%$ \\
$\begin{array}{l}\text { Total } \\
\text { Rata-rata }\end{array}$ & 35 & 44 & 9 & $26 \%$ \\
\hline
\end{tabular}

Berdasarkan tabel di atas dapat dilihat bahwa subjek TW memiliki skor yang rendah pada aspek peka terhadap bahasa isyarat yakni 4 dan meningkat menjadi 6 setelah diberikan konseling, artinya ada peningkatan sebesar 50\%. Pada aspek ikut merasakan skor yang diperoleh 6 dan meningkat menjadi 9 setelah diberikan konseling yang berarti ada peningkatan sebesar 50\%.

Pada aspek mengambil peran skor awal adalah 10 dan meningkat menjadi 12 yang berarti ada peningkatan sebesar $20 \%$ begitu juga pada aspek kontrol emosi dengan skor awal 8 dan meningkat menjadi 10 setelah diberikan konseling yang berarti ada peningkatan sebesar 25\%. Pada aspek empati yang dibangun berdasarkan kesadaran diri skor sebelum dan sesudah diberikan konseling tetap sama yakni 7 yang berarti tidak ada peningkatan. Namun jika dilihat secara keseluruhan pada saat pre test empati TW tergolong rendah dan meningkat sebesar $26 \%$ menjadi sangat tinggi. 
Pada subjek ketiga yakni AD hasil pre test dan post test empati dapat dilihat pada tabel di bawah ini:

Tabel 3. Hasil pre test dan post test empati pada subjek AD

\begin{tabular}{lcccc}
\hline \multicolumn{1}{c}{ Aspek } & Pretest & Posttest & \multicolumn{2}{c}{ Selisih } \\
& & & Skor & Persentasi \\
\hline $\begin{array}{l}\text { Ikut } \\
\text { merasakan }\end{array}$ & 5 & 9 & 4 & $80 \%$ \\
$\begin{array}{l}\text { Dibangun } \\
\text { berdasarkan }\end{array}$ & 6 & 6 & 0 & $0 \%$ \\
$\begin{array}{l}\text { kesadaran } \\
\text { diri }\end{array}$ & & & & \\
$\begin{array}{l}\text { Peka } \\
\text { terhadap }\end{array}$ & 2 & 6 & 4 & $200 \%$ \\
$\begin{array}{l}\text { isyarat } \\
\text { Mengambil }\end{array}$ & 9 & 12 & 3 & $33 \%$ \\
peran & & & & \\
$\begin{array}{l}\text { Kontrol } \\
\text { emosi }\end{array}$ & 7 & 11 & 4 & $57 \%$ \\
$\begin{array}{l}\text { Total } \\
\text { Rata-rata }\end{array}$ & 29 & 44 & 15 & $52 \%$ \\
\hline
\end{tabular}

Pada tabel di atas terlihat bahwa pada subjek $\mathrm{AD}$ nilai terendah terdapat pada aspek peka terhadap bahasa isyarat dengan skor 2 dan meningkat menjadi 6 setelah diberikan konseling, dengan kata lain peningkatannya sebesar 200\%. Pada aspek ikut merasakan skor awal yang diperoleh adalah 5 dan meningkat menjadi 9 atau mengalami peningkatan sebesar 80\%. Pada aspek mengambil peran skor awal yang diperoleh adalah 9 dan meningkat menjadi 12 setelah diberikan konseling, atau mengalami peningkatan sebesar 33\%.

Aspek kontrol emosi yang diperoleh AD sebelum perlakuan adalah 7 dan menigkat menjadi 11 setelah diberikan konseling yang berarti peningkatan yang terjadi sebesar 57\%. Sementara itu pada aspek empati yang dibangun berdasarkan kesadaran diri skor sebelum dan sesudah tetap sama yakni 6 yang berarti tidak ada peningkatan yang terjadi. Secara keseluruhan empati AD sebelum diberikan konseling sebesar 29 meningkat menjadi 44 yang berarti mengalami peningkatan sebesar $52 \%$.

Adapun perolehan hasil pre test dan post test hubungan interpersonal pada 3 orang mahasiswa program studi akuntansi yang menjadi kelompok eksperimen dapat dilihat pada tabel dibawah ini:

Tabel 4. Hasil pre test dan post test hubungan interpersonal pada subjek RN

\begin{tabular}{lcccc}
\hline \multicolumn{1}{c}{ Aspek } & Pretest & Posttest & \multicolumn{2}{c}{ Selisih } \\
& & & Skor & Persentasi \\
\hline $\begin{array}{l}\text { Mengenal } \\
\text { secara dekat }\end{array}$ & 8 & 12 & 4 & $50 \%$ \\
$\begin{array}{l}\text { Saling } \\
\text { memerlukan }\end{array}$ & 9 & 12 & 3 & $33 \%$ \\
$\begin{array}{l}\text { Pem ahaman } \\
\text { sifat pribadi }\end{array}$ & 10 & 12 & 2 & $20 \%$ \\
Bekerja sama & 7 & 8 & 1 & $14 \%$ \\
Total & 34 & 44 & 10 & $29 \%$ \\
Rata-rata & 8,5 & 11 & - & - \\
\hline
\end{tabular}

Berdasarkan tabel di atas dapat dilihat bahwa pada subjek RN aspek mengenal secara dekat miliki skor awal 8 dan meningkat menjadi 12 setelah diberikan konseling yang berarti ada peningkatan sebesar 50\%. Aspek saling memerlukan sebelum diberikan konseling skor awalnya 9 dan mengalami peningkatan sebesar $33 \%$ menjadi 12 setelah diberikan konseling.

Pada aspek pemahaman sifat pribadi skor awal yang diperoleh adalah 10 dan meningkat sebesar $20 \%$ menjadi 12 . Aspek bekerja sama pada RN memiliki skor awal 7 dan meningkat menjadi 8 artinya mengalami kenaikan sebesar 14\%. Secara keseluruhan hubungan interpersonal RN sebelum konseling tergolong cukup dengan skor 34 dan meningkat menjadi 44 yang tergolong sangat tinggi. Dengan demikian hubungan interpersonal RN meningkat sebesar 29\% setelah diberikan konseling. 
Hubungan interpersonal pada pre test dan post test pada subjek kedua TW dapat dilihat pada tabel di bawah ini:

Tabel 5. Hasil pre test dan post test hubungan interpersonal pada subjek TW

\begin{tabular}{lcccc}
\multicolumn{1}{c}{ Aspek } & Pretest & Posttest & \multicolumn{2}{c}{ Selisih } \\
& & & Skor & Persentasi \\
\hline $\begin{array}{l}\text { Mengenal } \\
\text { secara dekat }\end{array}$ & 7 & 10 & 3 & $43 \%$ \\
$\begin{array}{l}\text { Saling } \\
\text { memerlukan }\end{array}$ & 11 & 12 & 1 & $9 \%$ \\
$\begin{array}{l}\text { Pemahaman } \\
\text { sifat pribadi }\end{array}$ & 9 & 11 & 2 & $22 \%$ \\
Bekerja sama & 7 & 7 & 0 & $0 \%$ \\
Total & 34 & 40 & 6 & $18 \%$ \\
Rata-rata & 8,5 & 10 & - & - \\
\hline
\end{tabular}

Berdasarkan tabel di atas dapat dilihat bahwa pada subjek TW aspek mengenal secara dekat memiliki skor awal 7 dan meningkat menjadi 10 artinya ada peningkatan sebesar 43\%. Aspek saling memerlukan memiliki skor awal 11 dan meningkat menjadi 12 setelah diberikan konseling, artinya hanya mengalami peningkatan $9 \%$ saja. Pada aspek pemahaman sifat pribadi skor sebelum konseling 9 dan meningkat menjadi 11 setelah diberikan konseling, artinya ada peningkatan sebesar $22 \%$.

Pada aspek bekerja sama skor sebelum dan seseudah diberikan konseling tetap sama yakni 7 dengan demikian tidak ada peningkatan pada aspek bekerja sama pada subjek TW. Secara keseluruhan hubungan interpersonal TW sebelum diberikan konseling tergolong cukup dengan skor 34 dan meningkat menjadi 40 yang tergolong sangat tinggi, artinya ada peningkatan sebesar $18 \%$.

Adapun pre test dan post test hubungan interpersonal pada subjek ketiga yaitu AD dapat dilihat pada tabel di bawah ini:

Tabel 6. Hasil pre test dan post test hubungan

\begin{tabular}{lcccc} 
interpersonal pada subjek AD & & \\
\hline \multicolumn{1}{c}{ Aspek } & Pretest & Posttest & \multicolumn{2}{c}{ Selisih } \\
& & & Skor & Persentasi \\
\hline $\begin{array}{l}\text { Mengenal } \\
\text { secara dekat }\end{array}$ & 3 & 10 & 7 & $233 \%$ \\
$\begin{array}{l}\text { Saling } \\
\text { memerlukan }\end{array}$ & 6 & 10 & 4 & $67 \%$ \\
$\begin{array}{l}\text { Pem ahaman } \\
\text { sifat pribadi }\end{array}$ & 9 & 10 & 1 & $11 \%$ \\
$\begin{array}{l}\text { Bekerja sama } \\
\text { Total }\end{array}$ & 5 & 7 & 2 & \\
Rata-rata & 23 & 37 & 14 & $61 \%$ \\
\hline
\end{tabular}

Berdasarkan tabel di atas dapat dilihat bahwa aspek mengenal secara dekat pada subjek $\mathrm{AD}$ mengalami peningkatan yang sangat tinggi yakni sebesar 233\% di mana skor sebelum diberikan konseling 3 dan meningkat menjadi 10 setela dilakukan konseling sebanyak lima kali pertemuan. Aspek saling memerlukan meningkat sebesar $67 \%$ dengan skor awal 6 dan skor setelah diberikan konseling 10.

Pada aspek pemahaman sifat pribadi skor sebelum konseling yan diperoleh AD adalah 9 dan meningkat menjadi 10 setelah diberikan konseling, artinya ada peningkatan sebesar $11 \%$. Pada aspek kemampuan bekerja sama skor awal yang diperoleh AD adalah 5 dan meningkat menjadi 7 atau dengan kata lain ada peningkatan sebesar $40 \%$. Secara keseluruhan hubungan interpersonal $\mathrm{AD}$ mengalami peningkatan sebesar $61 \%$ di mana skor awal sebelum diberikan konseling adalah 23 yang berarti rendah, dan meningkatn menjadi 37 dengan kategori sangat tinggi.

Dari hasil pretest-postest $\mathrm{di}$ atas dapat disimpulkan bahwa penerapan buku panduan layanan konseling dengan model creative art untuk meningkatkan empati dan hubungan interpersonal pada mahasiswa dapat diterima sehingga dapat menjadi buku pedoman untuk 
meningkatkan empati dan hubungan interpesonal pada mahasiswa.

Berdasarkan pengujian pengembangan peningkatan empati postest pada kelompok eksperimen dan control diperoleh data di bawah ini:

Tabel 7. Hasil Pengujian Pengembangan Peningkatan Empati Postest Pada Kelompok Eksperimen dan Kontrol.

\begin{tabular}{cccccc}
\hline Statistik & $\begin{array}{c}\text { N } \\
\text { Mean } \\
\text { KE }\end{array}$ & $\begin{array}{c}\text { Mean } \\
\text { KK }\end{array}$ & Sd & $\begin{array}{c}\text { Sig 2 } \\
\text { tailed }\end{array}$ \\
\hline Empati & 3 & 46,67 & 36,33 & 8,33 & 0.043 \\
\hline
\end{tabular}

$H_{0}: \quad E_{1} \leq E_{2}$ (peningkatan empati posttest pada kelompok ekpserimen dan kelompok kontrol tidak berbeda)

$H_{1}: E_{1}>E_{2}$ (peningkatan empati postest pada kelompok eksperimen dan kelompok kontrol berbeda)

Nilai asymp sig (2 tailed) menunjukkan p-value. Karena p-value yang diperoleh sebesar $0.043<\alpha=5 \%$, maka $\mathrm{H}_{0}$ ditolak yang berarti bahwa terjadi perbedaan peningkatan Empati setelah diberi perlakuan antara kelompok ekperimen dan kelompok kontrol berbeda pada taraf nyata 5\%. Berdasarkan hasil pengujian ini dapat dikemukakan hipotesis penelitian yaitu penggunaan model creative art dalam konseling dapat meningkatkan empati pada mahsiswa politeknik Lp3i Medan Kampus Medan Baru diterima.

pengujian pengembangan peningkatan hubungan interpersonal postest pada kelompok eksperimen dan control diperoleh data di bawah ini:

Tabel 8. Hasil Pengujian Pengembangan Peningkatan Hubungan Interpersonal Postest Pada Kelompok Eksperimen dan Kontrol

\begin{tabular}{cccccc}
\hline Statistik & $\mathrm{N}$ & $\begin{array}{c}\text { Mean } \\
\text { KE }\end{array}$ & $\begin{array}{c}\text { Mean } \\
\text { KK }\end{array}$ & Sd & $\begin{array}{c}\text { Sig 2 } \\
\text { tailed }\end{array}$ \\
\hline $\begin{array}{c}\text { Hubungan } \\
\text { Interpersonal }\end{array}$ & 3 & 40,33 & 32 & 7,15 & 0.046 \\
\hline
\end{tabular}

$H_{0}: \quad E_{1} \leq E_{2}$ (peningkatan Hubungan Interpersonal postest pada kelompok ekpserimen dan kelompok kontrol tidak berbeda)

$H_{1}: E_{1}>E_{2}$ (peningkatan Hubungan Interpersonal postest pada kelompok eksperimen dan kelompok kontrol berbeda)

\section{Nilai asymp sig (2 tailed)} menunjukkan p-value. Karena p-value yang diperoleh sebesar $0.046<\alpha=5 \%$, maka $\mathrm{H}_{0}$ ditolak yang berarti bahwa adanya perbedaan peningkatan coping stress setelah diberi perlakuan model creative art dalam konseling antara kelompok ekperimen dan kelompok kontrol berbeda pada taraf nyata 5\%. Berdasarkan ini dikemukakan bahwa hipotesis penelitian : Model creative art dalam konseling dapat meningkatkan Hubungan Interpersonal pada mahasiswa diterima.

Adapun pengembangan peningkatan empati dapat dilihat pada tabel di bawah ini:

\begin{tabular}{lcccccc} 
Tabel 9. Pengembangan Peningkatan Empati \\
\hline $\begin{array}{l}\text { Statis } \\
\text { tika }\end{array}$ & $\begin{array}{l}\text { Kelompok } \\
\text { Ekp erimen } \\
\text { Pret } \\
\text { es }\end{array}$ & Postes & $\begin{array}{c}\text { Pening } \\
\text { katan }\end{array}$ & Pretes & Postes & $\begin{array}{c}\text { Pening } \\
\text { katan }\end{array}$ \\
\hline $\mathrm{N}$ & 3 & 3 & 3 & 3 & 3 & 3 \\
Mean & 33 & 46,67 & 13,67 & 35,33 & 36,33 & 1 \\
\hline KE $=$ Kelompok Eksperimen \\
KK = Kelompok Kontrol
\end{tabular}

Berdasarkan tabel di atas, KE mengalami rata-rata peningkatan sebesar 13,67 setelah diberi perlakuan model creative art dalam konseling. Adanya perubahan yang signifikan ditunjukkan selisih angka yang terjadi pada kelompok eksperimen dan kelompok kontrol 1 13,67 > 1) yang artinya model creative art dapat meningkatka emapti pada mahasiswa. 
Sementara itu pengembangan Baru. Hasil penelitian juga menunjukkan peningkatan hubungan interpersonal dapat terdapat perbedaan peningkatan dilihat pada tabel di bawah ini:

Tabel 10. Pengem bangan Peningkatan Hubungan Interpersonal

Statisti Kelompok Ekperim en Kelompok Kontrol

ka Pretes Postes Peningk Pretes Postes Peningk

\begin{tabular}{lllllll} 
& \multicolumn{5}{c}{ atan } & \multicolumn{2}{c}{ atan } \\
\hline $\mathrm{N}$ & 3 & 3 & 3 & 3 & 3 & 3 \\
Mean & 30,33 & 40,33 & 10 & 31 & 32 & 1 \\
\hline
\end{tabular}

KE $=$ Kelompok Eksperim en

$\mathrm{KK}=$ Kelompok Kontrol

Tabel di atas menunjukkan adanya tingkat perbedaan peningkatan yang di alami KE setelah diberi perlakuan model creative art dalam konseling. Rata-rata peningkatan sebesar 10 pada kelompok eksperimen dan pada kelompok kontrol rata-rata peningkatan hanya 1 . Dengan kata lain $\mathrm{KE}>\mathrm{KK}(10>1)$ yang berarti model creative art dalam konseling dapat meningkatkan hubungan interpersonal pada mahasiswa.

\section{SIMPULAN}

Berdasarkan hasil analisis dan pembahasan dalam penelitian ini, dapat dikemukakan simpulan model creative art dalam konseling untuk meningkatkan empati dan hubungan interpersonal pada mahasiswa Politeknik LP3i Medan Kampus Medan Baru dapat tersusun dengan pengembangan antara pretes dan postes pada empati dan hubungan interpersonal setelah diterapkan model creative art dalam konseling pada mahasiswa di LP3I Kampus Medan Baru.

\section{DAFTAR PUSTAKA}

Dian, W., \& Srifatmawati, M. (2012). Hubungan Interpersonal. Jakarta: Salemba Humanika.

Gladding, S. T. (1992). Counseling As An Art: the Creative Arts In Counseling. Alexandria: American Association For Counseling and Development.

Mahyudin, A. A. (2009). Menjadi Pemimpin Politik. Jakarta: Gram edia Pus taka utama.

Milfayetty, S. (2017). Innovationn In Teaching and Learning Through Creative Art Model. European Journal of Social Sciences Education and Research, 10(2), 119-124.

Milfayetty, S. (2017). Peningkatan Spiritual Wellness Melalui Konseling dengan Creative Art. Kaunseling Psikoterapi Berperspektif Islam, 63-68.

Prayitno. (2015). Konseling Integritas. Jakarta: Paramitra.

Sugiyono. (2015). Metode Penelitian dan Pengembangan. Bandung: Alfabeta.

Sutanti, T. (2015). Efektivitas Teknik Modeling Untuk Meningkatkan Empati Mahasiswa Prodi BK Universitas Ahmad Dahlan. Jurnal Psikologi Pendidikan \& Konseling, 1(2), 188-198. spesifikasi sintaks, sistem sosial, prinsipprinsip reaksi yang dituangkan dalam buku panduan pelaksanaan berikut lembar evaluasi perkembangan.

Model creative art dalam konseling dapat digunakan sebagai model konseling yang dapat meningkatkan empati dan hubungan interpersonal pada mahasiswa. Penerapan model creative art dalam konseling dapat meningkatkan empati dan hubungan interpersonal pada mahasiswa Politeknik LP3i Medan Kampus Medan 